\title{
Keteguhan Rekat Kayu Lapis Sengon Menggunakan Perekat Lignin- Formaldehida dengan Dua Macam Bahan Pengisi (Bonding Strength of Sengon Plywood Using Lignin-Formaldehyde Adhesive with Two Types of Fillers)
}

\author{
Achmad Supriadi ${ }^{*}$, Adi Santoso, Rohmah Pari \\ Pusat Penelitian dan Pengembangan Hasil Hutan, Jalan Gunung Batu No. 5, Bogor \\ *Penulis korespondensi: susupriadi@gmail.com
}

\begin{abstract}
Various efforts have been done to reduce the cost, such as finding a suitable mixture of fillers in the adhesive formulation. The aim of this study was to determine the characteristic of ligninformaldehyde (LF) adhesive and the effect of different content of coconut shell flour and kaolin in the adhesive of lignin on the bonding strength of sengon plywood. Coconut shell flour and kaolin filler content were varied, i.e. $0 \%, 10 \%, 20 \%, 30 \%$, and $40 \%$. The plywood of (20x20x 1.5$) \mathrm{cm}^{3}$ size was prepared using a liquid lignin-formaldehyde (LF) with a glue spread of $170 \mathrm{~g} \mathrm{~m}^{-2}$ surfaces. Bonding strength of plywood was tested to determine the quality of sengon plywood. The results showed that LF adhesive was appeared as a reddish-brown liquid and there were no foreign substances, solid resin content ranges from 31.85 to $35.68 \%$, viscosity of 1.2 poise, acidity $(\mathrm{pH})$ of 11.5 , and gelatinized time ranges from 24.20-25.96 minutes. The type and filler content had a significant effect on the bonding strength of sengon plywood. Increasing of the filler content tended to increase the bonding strength of sengon plywood to $30 \%$. The bonding strength of sengon plywood produced using the content of either coconut shell or kaolin flour fillers up to $30 \%$ complied with German Standards requirement. The maximum bonding strength value was obtained on adhesives using both types of fillers as much as $10 \%$.
\end{abstract}

Keywords: bonding strength, coconut shell flour, filler, kaolin, lignin-formaldehyde

\begin{abstract}
Abstrak
Berbagai upaya pengurangan biaya perekat dilakukan, salah satunya adalah menggunakan campuran bahan pengisi pada formulasi perekat. Penelitian ini bertujuan untuk mengetahui karakterisasi perekat lignin formaldehida (LF) serta pengaruh kadar tepung tempurung kelapa dan kaolin dalam perekat LF terhadap keteguhan rekat kayu lapis sengon. Sebagai bahan pengisi, digunakan tepung tempurung kelapa dan kaolin masing-masing menggunakan 5 variasi kadar yaitu $0 \%, 10 \%, 20 \%, 30 \%$, dan $40 \%$. Kayu lapis berukuran $(20 \times 20 \times 1,5) \mathrm{cm}^{3}$ dibuat dengan perekat LF cair dengan bobot labur perekat $170 \mathrm{~g} \mathrm{~m}^{-2}$ permukaan. Hasil penelitian menunjukkan bahwa karakterisasi perekat LF adalah cairan perekat berwarna cokelat kemerahmerahan dan tidak terdapat bahan asing, kadar resin padat berkisar antara 31,85-35,68\%, viskositas 1,2 poise, keasaman $(\mathrm{pH})$ 11,5, dan waktu gelatinasi berkisar antara 24,20-25,96 menit. Jenis dan kadar bahan pengisi berpengaruh nyata terhadap keteguhan rekat kayu lapis sengon. Peningkatan kadar bahan pengisi cenderung menaikkan keteguhan rekat kayu lapis sampai kadar $30 \%$. Kayu lapis yang dihasilkan baik menggunakan bahan pengisi tepung tempurung kelapa maupun kaolin sampai dengan kadar 30\%, keteguhan rekatnya memenuhi persyaratan Standar Jerman. Nilai keteguhan rekat maksimum diperoleh pada perekat yang menggunakan kedua jenis bahan pengisi sebanyak $10 \%$.
\end{abstract}

Kata kunci: bahan pengisi, kaolin, keteguhan rekat, lignin formaldehida, tepung tempurung kelapa 


\section{Pendahuluan}

Produk kayu lapis pernah menjadi andalan ekspor terbesar kedua Indonesia setelah produk minyak bumi. Akan tetapi kondisi kini berbeda terutama semenjak krisis bahan baku kayu melanda industri kayu di Indonesia sebagai akibat dari menurunnya kemampuan pasokan kayu dari hutan alam. Balfas (2010) menyatakan bahwa dalam berbagai forum komunikasi ilmiah dilaporkan defisit kayu nasional akan mencapai lebih dari 50 juta $\mathrm{m}^{3}$ per tahun. Untuk mengatasi masalah ini, pemerintah telah melakukan berbagai upaya diantaranya dengan mendorong penanaman jenisjenis kayu cepat tumbuh (fast-growing species) seperti mangium, sengon, rasamala, gmelina, jabon, dan lain-lain melalui pembangunan hutan tanaman, baik berupa hutan tanaman industri (HTI) maupun hutan rakyat (HR) (KLHK 2016). Ke depannya diharapkan keberadaan kayu dari hutan tanaman dapat mensubstitusi kekurangan pasokan kayu dari hutan alam. Kayu yang berasal dari hutan tanaman sebagian besar memiliki diameter kecil. Kondisi kayu seperti ini bila langsung diolah akan menghasilkan papan dan balok gergajian dengan ukuran dimensi yang sempit, sehingga memiliki keterbatasan dalam pemanfaatannya. Untuk mengatasi hal ini, dolok kayu dapat dikupas dengan menggunakan mesin kupas menghasilkan lembaran-lembaran tipis yang disebut dengan venir. Dari venir tersebut kemudian dapat dibuat produk, salah satunya yang disebut dengan kayu lapis.

Kayu lapis adalah suatu produk yang diperoleh dengan cara menyusun bersilangan tegak lurus lembaran venir yang diikat dengan perekat (Kliwon \& Iskandar 2008). Dewasa ini perekat yang umum digunakan berupa perekat sintetis. Menurut Pizzi (1998), dalam industri kayu lapis penggunaan perekat dapat mencapai $30 \%$ dari total biaya produksi. Upaya pengurangan komponen biaya perekat perlu dilakukan atara lain dengan mencampurkan bahan pengisi (filler) dalam formulasi perekat. Pengurangan komponen biaya perekat sintetis telah diupayakan untuk mengeksplorasi penelitian pembuatan perekat bukan sintetis seperti perekat alam dari tanin atau lignin (Maloney 1977).

Bahan pengisi merupakan bahan berbentuk tepung yang relatif tidak mempunyai sifat perekatan dari campuran perekat (Sutigno 1988). Bahan pengisi ditambahkan pada perekat dengan maksud untuk mengurangi penembusan yang terlalu berlebih dari perekat ke dalam kayu, selain untuk memperbaiki sifat-sifat perekat seperti mengisi celah (Landrock \& Ebnesajjad 2008). Bahan pengisi dapat dikelompokkan ke dalam 2 (dua) kelompok besar (Prayitno 1986), yaitu (1) kelompok bahan pengisi organik seperti furafil, kulit tempurung (shell), bubuk kayu (wood flour), dan sisa dari pabrik pengolahan pulp dan kertas, dan (2) kelompok bahan pengisi anorganik seperti mineral, tanah lempung, dan lain sebagainya. Penambahan bahan pengisi ke dalam perekat berdampak positif yaitu mengurangi penetrasi perekat yang berlebihan dan menahan molekul perekat serta sekaligus mengikatnya pada posisi garis rekat selama proses pengempaan (Prayitno 1986). Akan tetapi penambahan bahan pengisi yang berlebihan juga berdampak negatif yaitu mengakibatkan terlalu cepatnya perekat mengering, sehingga perekatan menjadi tidak optimal. Penelitian ini menggunakan bahan pengisi berupa tepung tempurung kelapa dan kaolin. Tepung tempurung kelapa termasuk kelompok bahan pengisi organik, 
sedangkan kaolin termasuk anorganik, sehingga akan diperoleh gambaran kualitas kayu lapis menggunakan perekat yang telah ditambahkan oleh masingmasing bahan pengisi tersebut. Penggunaan kedua bahan pengisi tersebut mengingat potensinya cukup besar di Indonesia.

Tulisan ini menyajikan hasil penelitian pengaruh dua jenis bahan pengisi yaitu tepung tempurung kelapa dan kaolin dalam perekat lignin formaldehida terhadap keteguhan rekat kayu lapis sengon. Kadar tepung tempurung kelapa maupun kaolin sebagai bahan pengisi menggunakan 5 variasi yaitu $0 \%, 10 \%$, $20 \%$, 30\%, dan 40\% dengan bobot labur perekat masing-masing $170 \mathrm{~g} \quad \mathrm{~m}^{-2}$ permukaan. Kayu lapis yang dibuat berukuran $(20 \times 20 \times 1,5) \quad \mathrm{cm}^{3}$. Variasi kadar tepung tempurung kelapa dan kaolin sebagai bahan pengisi perekat bertujuan agar dapat diketahui mutu kayu lapis yang dihasilkan dari berbagai variasi kadar kedua macam bahan tersebut serta penggunaan kadar bahan pengisi yang optimal. Perekat yang digunakan adalah lignin formaldehida (LF) cair.

\section{Bahan dan Metode}

\section{Bahan dan alat}

Bahan yang digunakan dalam penelitian ini adalah lignin hasil isolasi laboratorium, larutan formaldehida 37\%, paraformaldehida kristal, bahan pengisi berupa tepung tempurung kelapa dan kaolin, $\mathrm{NaOH}$ teknis, $\mathrm{H}_{2} \mathrm{SO}_{4}$, aquades, dan venir kayu sengon (Paraserianthes falcataria). Peralatan yang digunakan meliputi mesin kupas, pemotong venir, gergaji mesin meja, mesin kempa dingin, kempa panas, oven, meteran, gelas ukur, pengaduk, pipet tetes, penangas air, viscosimeter, piknometer, desikator, ekstraktor, timbangan, kuas, termometer, kaliper, dan mesin uji UTM (Universal Testing Machine).

\section{Pembuatan resin lignin formaldehida (LF)}

Lignin dicampur dengan $\mathrm{NaOH} 10 \%$ dalam gelas piala lalu diaduk pada suhu ruangan sampai membentuk pasta. Kemudian ditambahkan larutan $\mathrm{NaOH}$ $50 \%$ sambil diaduk sampai semua pasta terlarut, lalu dikondisikan sampai mencapai $\mathrm{pH}$ 11. Selanjutnya ditambahkan larutan formaldehida $37 \%$ sambil diaduk lalu larutan $\mathrm{NaOH} 10 \%$ dimasukkan dan campuran diaduk lagi sampai mencapai pH 11. Reaksi di atas dilakukan pada suhu $80-90{ }^{\circ} \mathrm{C}$ dan perbandingan lignin dengan formaldehida adalah (1:2) mol.

\section{Karakterisasi perekat}

Karakterisasi perekat dianalisis dengan uji kenampakan dan uji laboratoris. Uji kenampakan (visual) dilakukan melalui pengamatan terhadap butiran padat, partikel kasar, dan benda asing lainnya dengan membedakan gelembung udara yang mungkin terbentuk. Uji laboratoris meliputi kadar padatan, kekentalan (viskositas), keasaman ( $\mathrm{pH})$, dan waktu gelatinasi.

Kadar padatan perekat LF dianalisis dengan membandingkan bobot kering perekat $(\mathrm{Wt})$ yang telah dikeringkan pada oven dengan suhu $130 \pm 2{ }^{\circ} \mathrm{C}$ dengan bobot awal perekat (Wo). Kadar padatan perekat dihitung menggunakan persamaan 1 .

Kadar padatan $(\%)=\frac{W t}{W o} \times 100 \%(1)$

Kekentalan perekat (viskositas) dilakukan menggunakan alat viscometer dimana sejumlah perekat LF dituangkan ke dalam bejana viscometer kemudian 
diukur kekentalannya dengan satuan poise. Pengukuran keasaman $(\mathrm{pH})$ perekat dianalisis dengan kertas indikator $\mathrm{pH}$. Contoh perekat LF dimasukkan ke dalam gelas piala berukuran $100 \mathrm{~mL}$ dan pH-nya diamati dengan kertas indikator $\mathrm{pH}$. Sedangkan waktu gelatinasi diukur dengan pengamatan perekat LF yang dimasukkan ke dalam tabung reaksi untuk dipanaskan dalam penangas air pada suhu $90{ }^{\circ} \mathrm{C}$. Waktu gelatinasi diperoleh dengan mencatat durasi waktu yang diperlukan perekat mulai dari perekat dipanaskan sampai dengan perekat tidak mengalir saat dimiringkan.

\section{Pembuatan kayu lapis}

Vinir berukuran $(20 \times 20 \times 0,5) \mathrm{cm}^{3}$ diampelas agar permukaanya halus, kemudian dikeringkan dalam oven sampai mencapai kadar air 8-12\%. Permukaan venir dilabur dengan campuran perekat sebanyak $170 \mathrm{~g} \mathrm{~m}^{-2}$, sebagai bahan pengisi digunakan tempurung kelapa dan kaolin, dengan kadar bervariasi 10\%, 20\%, 30\% dan $40 \%$ serta $0 \%$ sebagai kontrol, semuanya dari bobot perekat cair. Venir yang telah dilaburi perekat sebanyak 13,6 $\mathrm{g}$ disusun secara bersilangan tegak lurus menjadi kayu lapis ukuran $(20 \times 20 \times 1,5) \mathrm{cm}^{3}$, kemudian dikempa dingin selama 15 menit. Alat kempa hasil rekayasa Pusat Litbang Hasil Hutan, bekerja secara manual, tidak dilengkapi dengan pengukur tekanan. Tekanan dihentikan bila perekat terlihat sudah mengisi sepanjang garis rekat. Selanjutnya dikempa panas dengan mesin kempa Becker and Van Hullen pada suhu 130 ${ }^{\circ} \mathrm{C}$ selama 5 menit dengan tekanan $15 \mathrm{~kg}$ $\mathrm{cm}^{-2}$. Pengkondisian selama 1 minggu dilakukan sebelum pengujian.

\section{Pengujian kayu lapis}

Contoh uji dibuat dengan ukuran $(10 \times 2,5 \times 1,5) \quad \mathrm{cm}^{3} \quad$ masing-masing sebanyak 4 (empat) ulangan. Sebelum dilakukan pengujian, contoh uji diberi perlakuan sesuai standar Jerman tipe AW 100 (DIN 1975).

\section{Analisis data}

Data hasil pengujian dianalisis menggunakan rancangan acak lengkap faktorial (Sudjana 2004). Perlakuan (faktor) meliputi jenis bahan pengisi yang terdiri atas dua taraf (tepung tempurung kelapa dan kaolin) dan kadar pengisi yang terdiri dari 5 taraf $(0,10$, 20, 30, dan 40\%). Pada setiap perlakuan dilakukan 4 (empat) kali ulangan baik untuk uji keteguhan rekat maupun karakterisasi perekat.

Pengaruh macam dan kadar bahan pengisi terhadap keteguhan rekat dianalisis dengan uji sidik ragam (Sudjana 2004). Bilamana terjadi pengaruh nyata maka analisis dilanjutkan dengan uji Duncan. Hubungan antara kadar pengisi dengan keteguhan rekat kayu lapis diketahui dengan analisis regresi. Pengolahan data menggunakan software Minitab (Hendradi 2012).

\section{Hasil dan Pembahasan}

\section{Karakteristik lignin formaldehida}

Perekat lignin formaldehida (LF) yang berasal dari lindi hitam dianalisis karakteristiknya secara visual dan laboratoris, hasilnya disajikan pada Tabel 1, sedangkan komposisi ramuan perekat dan sifatnya disajikan pada Tabel 2.

Pada Tabel 1, tampak bahwa dari pengamatan secara visual cairan perekat LF berwarna cokelat kemerah-merahan, mirip dengan phenol-formaldehida (PF), dan tidak terdapat bahan asing. Kadar resin padat perekat LF berkisar 31,85$35,68 \%$, yang menggambarkan jumlah

Keteguhan Rekat Kayu Lapis Sengon Menggunakan Perekat Lignin-Formaldehida dengan 
resin yang terbentuk sebagai hasil reaksi polimerisasi. Makin tinggi kadar resin yang diperoleh maka makin banyak jumlah molekul dalam polimer yang diduga akan berperan dalam reaksi antara perekat dengan kayu. Kadar resin padat menunjukkan banyaknya jumlah partikel dalam perekat. Semakin banyak partikel perekat yang bereaksi dengan kayu pada proses perekatan, akan meningkatkan keteguhan rekatnya (Santoso et al. 2016). Kadar resin padat perekat LF pada penelitian ini mendekati standar perekat PF menurut standar SNI (1998). Kadar resin padat perekat LF ini juga lebih tinggi dibanding perekat tanin resorsinol formaldehida (TRF), yaitu sebesar 32,72\% (Setyarini 2007).

Nilai viskositas berpengaruh terhadap kemampuan perekat menembus pori-pori kayu dan masa simpan perekat (Maloney 1977). Perekat dengan viskositas tinggi mempunyai masa simpan yang singkat karena lebih cepat mengeras dan kualitas perekatannya menjadi rendah (Santoso 2001, Santoso et al. 2016). Perekat LF memiliki nilai viskositas yang besarnya berada dalam standar perekat PF (SNI 1998) yang berarti memiliki masa simpan yang sama dengan perekat PF. Bila dibandingkan dengan perekat TRF, masa simpan perekat LF lebih singkat karena nilai viskositasnya lebih tinggi dibanding perekat TRF (0,88 poise). Perekat LF juga memiliki kadar keasaman $(\mathrm{pH})$ sebesar 11,5 yang berarti berada dalam standar perekat PF (SNI 1998).

Perekat dengan kadar padatan tinggi dan viskositas yang sesuai, akan membentuk ikatan yang optimum sehingga dihasilkan daya rekat yang memuaskan (Maloney 1977). Perekat LF dapat berikatan dengan partikel kayu melalui ikatan permukaannya. Proses perekatan terjadi dengan melibatkan perekatan mekanik dan perekatan spesifik.

Tabel 1 Karakteristik lignin formaldehida

\begin{tabular}{|c|c|c|c|c|}
\hline \multirow{2}{*}{\multicolumn{2}{|c|}{ Parameter uji }} & \multicolumn{3}{|c|}{ Jenis perekat } \\
\hline & & \multicolumn{2}{|c|}{ Lignin formaldehida $* \quad \mathrm{Pr}$} & \\
\hline Uji visual & & \multicolumn{2}{|c|}{$(+)$} & $\frac{\text { ol formaldehida } * *}{(+)}$ \\
\hline Bahan asing & & \multicolumn{2}{|c|}{$(-)$} & $(-)$ \\
\hline Kadar resin pac & & \multicolumn{2}{|c|}{$31,85-35,68$} & Minimal 36 \\
\hline Viskositas, poi & & \multicolumn{2}{|c|}{1,2} & $0,5-5,0$ \\
\hline Keasaman, pH & & \multicolumn{2}{|c|}{11,5} & $10,0-13,0$ \\
\hline Waktu gelatina & & \multicolumn{2}{|c|}{$24,20-25,96$} & $3-30$ \\
\hline \multicolumn{5}{|c|}{$\begin{array}{l}\text { Keterangan: * = Rata-rata dari } 4 \text { kali ulangan; }(+)=\text { cairan berwarna cokelat kemerah-merahan; }(-) \\
\text { Tidak ada, ** = SNI (1998). Sumber: SNI (1998). }\end{array}$} \\
\hline \multicolumn{5}{|c|}{$\begin{array}{l}\text { Tabel } 2 \text { Kekentalan, kadar resin padat, dan waktu gelatinasi ramuan perekat Lignir } \\
\text { Formaldehida }\end{array}$} \\
\hline \multicolumn{2}{|c|}{ Bahan pengisi } & \multirow{2}{*}{$\begin{array}{l}\text { Kekentalan, } \\
\text { Poise }\end{array}$} & \multirow{2}{*}{$\begin{array}{l}\text { Kadar resin padat, } \\
\%\end{array}$} & \multirow{2}{*}{$\begin{array}{l}\text { Waktu gelatinasi, } \\
\text { menit }\end{array}$} \\
\hline Jenis & Kadar, \% & & & \\
\hline \multirow{5}{*}{$\begin{array}{l}\text { Tepung } \\
\text { tempurung } \\
\text { kelapa }\end{array}$} & 0 & 1,20 & 31,87 & 25,74 \\
\hline & 10 & 3,70 & 32,77 & 25,47 \\
\hline & 20 & 7,95 & 33,75 & 25,07 \\
\hline & 30 & 9,50 & 34,90 & 24,67 \\
\hline & 40 & 11,15 & 35,57 & 24,35 \\
\hline \multirow{5}{*}{ Kaolin } & 0 & 1,20 & 31,90 & 25,79 \\
\hline & 10 & 2,55 & 32,75 & 25,50 \\
\hline & 20 & 4,25 & 33,80 & 25,20 \\
\hline & 30 & 8,60 & 34,92 & 24,47 \\
\hline & 40 & 11,10 & 35,57 & 24,30 \\
\hline
\end{tabular}


Perekatan mekanik terjadi karena adanya sebagian perekat masuk ke dalam poripori kayu yang kemudian kering dan mengeras. Sementara perekatan spesifik terjadi dengan melibatkan ikatan-ikatan kimia, yaitu ikatan hidrogen dan ikatan Van der Walls (Ruhendi et al. 2007). Menurut Achmadi (1990) dan Rachmawati et al. (2018), ikatan hidrogen terjadi karena perekat memiliki gugus hidroksil yang memungkinkan adanya ikatan dengan komponen kayu yang juga memiliki gugus hidroksil seperti selulosa dan lignin.

Karakteristik LF berupa kadar padat, viskositas dan keasaman semuanya sesuai dengan standar PF. Keasaman $(\mathrm{pH}) \mathrm{LF}$ sengaja dikondisikan basa $(\mathrm{pH}$ 11,5), dengan tujuan untuk memperlambat reaksi polimerisasi, sehingga perekat cair stabil dalam waktu relatif lama ketika disimpan.

Kekentalan tertinggi (Tabel 2) terdapat pada formulasi perekat yang menggunakan bahan pengisi sebanyak $40 \%$, baik tepung tempurung kelapa maupun kaolin. Kekentalan berikutnya menurun pada penggunaan bahan pengisi berturut-turut sebanyak 30\%, 20\%, dan seterusnya. Kekentalan terendah terjadi pada formulasi perekat tanpa bahan pengisi (kontrol). Terdapat kecenderungan makin tinggi kadar kedua jenis bahan pengisi, makin meningkatkan kekentalan perekat LF. Kekentalan perekat berperan penting dalam proses perekatan. Untuk memperoleh perekatan yang baik diperlukan perekat dengan kekentalan yang optimum. Bila penambahan bahan pengisi telah menghasilkan kekentalan optimum, sebaiknya ditambahkan air secukupnya untuk memperoleh kekentalan yang diperlukan. Namun demikian, penambahan bahan pengisi pada batasbatas tertentu cenderung akan menurunkan keteguhan rekat kayu lapis. Hal ini diduga disebabkan berkurangnya konsentrasi lignin formaldehida dalam campuran perekat sebagai akibat peningkatan kadar bahan pengisi dan penambahan air

Selain kekentalan, pada Tabel 2 juga tampak kadar resin padat tertinggi terdapat pada ramuan perekat yang menggunakan bahan pengisi dengan kadar $40 \%$, kemudian kadar resin padat menurun berturut-turut pada kadar $30 \%$, $20 \%$, dan $10 \%$. Perekat yang tidak menggunakan bahan pengisi mengandung kadar resin padat paling rendah. Makin tinggi kadar bahan pengisi, makin tinggi kadar resin padat, baik pada bahan pengisi tepung tempurung kelapa maupun kaolin.

Waktu gelatinasi tertinggi terdapat pada ramuan perekat yang tidak menggunakan bahan pengisi (kontrol). Waktu gelatinasi berikutnya menurun pada penggunaan bahan pengisi berturut-turut sebanyak 10\%, 20\%, 30\%, dan 40\% (Tabel 2). Makin tinggi kadar bahan pengisi, makin rendah waktu gelatinasi, baik pada bahan pengisi tepung tempurung kelapa maupun kaolin.

Kekentalan perekat memiliki hubungan yang erat dengan kadar kedua jenis bahan pengisi, sebagaimana terlihat pada Gambar 1. Hubungan tersebut berupa regresi linier dengan hasil sidik regresi adalah $\mathrm{Yt}=1,560+0,257 \mathrm{Xt}$ dan $\mathrm{Yk}=$ $0,370+0,2585 \mathrm{Xk}$. Nilai koefisien bertanda positif baik pada kekentalan perekat LF menggunakan bahan pengisi tepung tempurung kelapa $(r=0,965)$ maupun yang menggunakan bahan pengisi kaolin $(\mathrm{r}=0,958)$. Hal ini menunjukkan bahwa makin tinggi kadar bahan pengisi ditambahkan pada perekat, makin tinggi kekentalan perekat tersebut. 


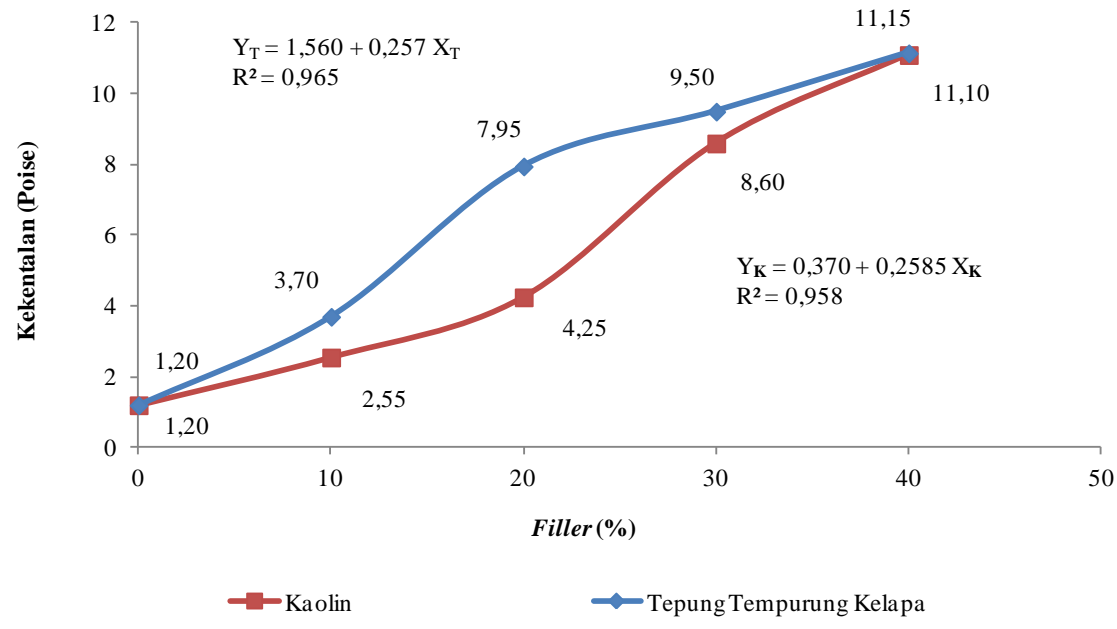

Keterangan:

$\mathrm{Y}_{\mathrm{T}}=$ Kekentalan perekat LF menggunakan bahan pengisi tepung tempurung kelapa

$\mathrm{Y}_{\mathrm{K}}=$ Kekentalan perekat LF menggunakan bahan pengisi kaolin

$\mathrm{X}_{\mathrm{T}}=$ Bahan pengisi tepung tempurung kelapa

$\mathrm{X}_{\mathrm{K}}=$ Bahan pengisi kaolin

Gambar 1 Hubungan antara kadar pengisi (filler) dengan kekentalan perekat.

\section{Keteguhan rekat}

Pengujian kualitas perekat dengan campuran dua jenis bahan pengisi ditelaah dengan pendekatan keteguhan rekat pada contoh uji kayu lapis sengon, yang hasilnya disajikan pada Tabel 3.

Pada Tabel 3 tampak bahwa keteguhan rekat kayu lapis sengon berkisar antara $8,86-13,47 \mathrm{~kg} \mathrm{~cm}^{-2}$. Nilai keteguhan rekat tertinggi terdapat pada kayu lapis sengon yang menggunakan campuran perekat LF dengan bahan pengisi kaolin kadar $10 \%$ yaitu $13,47 \%$. Nilai keteguhan rekat terkecil pada kayu lapis sengon menggunakan perekat yang sama dengan bahan pengisi tepung tempurung kelapa kadar $40 \%$ yaitu $8,86 \%$. Keteguhan rekat kayu lapis yang menggunakan kedua jenis bahan pengisi kadar $0 \%, 10 \%, 20 \%$, dan $30 \%$ memenuhi standar Jerman, karena nilai keteguhan rekatnya leih dari $10 \mathrm{~kg} \mathrm{~cm}^{-2}$. Terdapat kecenderungan peningkatan kadar bahan pengisi sampai batas tertentu dapat meningkatkan keteguhan rekat kayu lapis. Hal ini disebabkan adanya peningkatan kekentalan perekat, sehingga jumlah perekat yang meresap ke dalam venir tidak terlalu banyak dan garis rekat tidak terlampau tipis. Akan tetapi, setelah kadar bahan pengisi melebihi batas, keteguhan rekatnya akan menurun, karena semakin sedikit perekat LF pada luas permukaan venir.

Hasil penelitian Filoteo (1972) dan Kollmann et al. (1975) menyatakan bahwa penggunaan bahan pengisi sebaiknya berkisar antara 10-20\%. Pada penelitian ini terbukti bahwa kayu lapis yang menggunakan bahan pengisi tempurung kelapa maupun kaolin menghasilkan keteguhan rekat tertinggi masing-masing yaitu $11,93 \mathrm{~kg} \mathrm{~cm}^{-2}$ dan $13,47 \mathrm{~kg} \mathrm{~cm}^{-2}$. Untuk mengetahui pengaruh macam dan kadar bahan pengisi terhadap keteguhan rekat dianalisis dengan uji sidik ragam. Hasil analisis keragaman dan hasil uji lanjutannya (Duncan) disajikan pada Tabel 4 dan Tabel 5. 
Tabel 3 Keteguhan rekat kayu lapis sengon

\begin{tabular}{lrrrrc}
\hline \multirow{2}{*}{ Jenis bahan pengisi } & \multicolumn{5}{c}{ Keteguhan rekat, $\mathrm{kg} \mathrm{cm}^{-2}$} \\
\cline { 2 - 6 } & \multicolumn{5}{c}{ Kadar bahan pengisi, \% } \\
\cline { 2 - 6 } & \multicolumn{1}{c}{10} & \multicolumn{1}{c}{20} & \multicolumn{1}{c}{30} \\
\hline Tepung tempurung kelapa & 10,69 & 11,93 & 11,87 & 10,91 & 8,86 \\
Simpangan baku & 0,26 & 0,32 & 0,33 & 0,19 & 0,14 \\
Kaolin & 12,57 & 13,47 & 12,90 & 10,76 & 9,65 \\
Simpangan baku & 0,53 & 0,31 & 0,28 & 0,20 & 0,32 \\
\hline
\end{tabular}

Tabel 4 Analisis keragaman keteguhan rekat kayu lapis sengon

\begin{tabular}{lrccc}
\hline \multicolumn{1}{c}{ Sumber keragaman } & $\mathrm{db}$ & Kuadrat tengah & F Hitung & P-value \\
\hline Perlakuan & 9 & 8,56 & $55,63 * *$ & $0,0001^{*}$ \\
A & 1 & 10,12 & $85,23^{* *}$ & $0,0001^{*}$ \\
B & 4 & 15,51 & $6,77^{* *}$ & $0,0001^{*}$ \\
Interaksi & 4 & 1,23 & & \\
Kesalahan & 21 & 0,18 & & \\
Jumlah & 39 & & & \\
\hline
\end{tabular}

Keterangan: $\mathrm{A}=$ Jenis bahan pengisi; $\mathrm{B}=$ Kadar bahan pengisi; $\mathrm{AB}=$ Interaksi $\mathrm{A}$ dan $\mathrm{B} ; \mathrm{db}=$ Derajat bebas; $*$ = Berbeda nyata.

Tabel 5 Uji beda Duncan terhadap keteguhan rekat kayu lapis sengon

\begin{tabular}{lccccc}
\hline \multirow{2}{*}{ Jenis bahan pengisi } & \multicolumn{5}{c}{ Keteguhan rekat, kg cm } \\
\cline { 2 - 6 } & 0 & 10 & 20 & 30 & 40 \\
\cline { 2 - 6 } & $10,69 \mathrm{~d}$ & $11,93 \mathrm{c}$ & $11,87 \mathrm{c}$ & $10,91 \mathrm{~d}$ & $8,86 \mathrm{f}$ \\
Tepung tempurung kelapa & $12,57 \mathrm{~b}$ & $13,47 \mathrm{a}$ & $12,90 \mathrm{~b}$ & $10,76 \mathrm{~d}$ & $9,65 \mathrm{e}$ \\
Kaolin & &
\end{tabular}

Keterangan: Huruf yang tidak sama menunjukkan berbeda nyata.

Hasil analisis sidik ragam (Tabel 4) menunjukkan bahwa jenis dan kadar bahan pengisi serta interaksinya berpengaruh nyata terhadap keteguhan rekat kayu lapis. Hasil uji lanjutan Duncan menunjukkan bahwa terdapat perbedaan nyata nilai keteguhan antara perekat menggunakan bahan pengisi kaolin kadar $10 \%$ dengan kadar bahan pengisi lainnya, yang berarti penggunaan bahan pengisi kaolin $10 \%$ adalah yang optimal. Dengan kadar bahan pengisi yang sama, penggunaan bahan pengisi kaolin menghasilkan nilai keteguhan rekat lebih tinggi dibandingkan dengan yang menggunakan tepung tempurung kelapa, kecuali pada kadar 30\%.

Keteguhan rekat kayu lapis memiliki hubungan yang erat dengan kadar kedua jenis bahan pengisi, seperti terlihat pada Gambar 2, dengan hasil sidik regresi adalah $\mathrm{Yt}=10,719+0,167 \mathrm{Xt}-0,005$
$\mathrm{Xt}^{2}$ dan $\mathrm{Yk}=12,781+0,074 \mathrm{Xk}-0,004$ $\mathrm{Xk}^{2}$. Hubungan tersebut berupa regresi kuadratik dengan nilai korelasi yang menunjukkan bahwa terdapat hubungan yang erat baik antara keteguhan rekat dengan bahan pengisi tepung tempurung kelapa $(r=0,998)$ maupun antara keteguhan rekat dengan bahan pengisi kaolin $(r=0,929)$. Kadar bahan pengisi maksimum yang keteguhan rekatnya masih memenuhi standar Jerman adalah $30 \%$. Sementara nilai keteguhan rekat maksimum tercapai pada penggunaan bahan pengisi kaolin kadar 10\%.

Penghematan biaya perekat dalam pembuatan kayu lapis, dapat diupayakan dengan menggunakan filler kadar $30 \%$, karena pada kadar tersebut keteguhan rekat kayu lapis masih memenuhi standar Jerman. Akan tetapi, apabila yang menjadi prioritas adalah keteguhan rekat, maka dapat menggunakan bahan pengisi dengan kadar $10 \%$. 


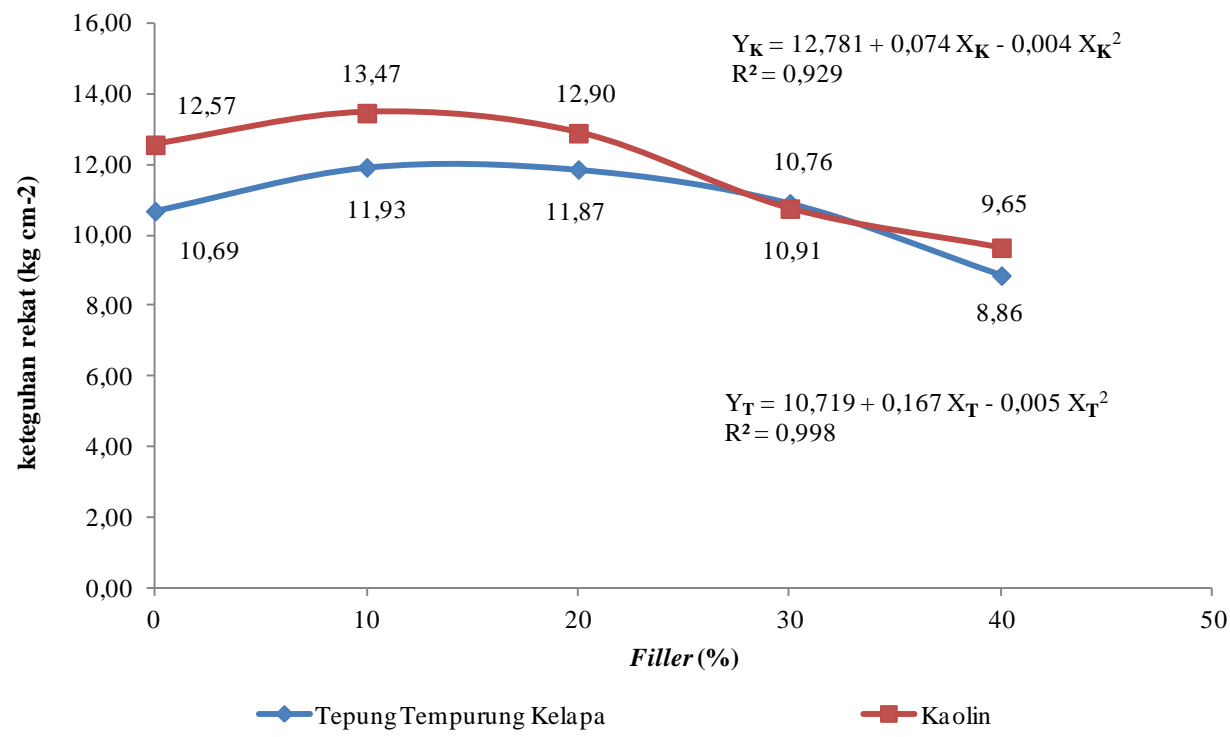

Keterangan:

$\mathrm{Y}_{\mathrm{T}}=$ Keteguhan rekat menggunakan bahan pengisi tepung tempurung kelapa

$\mathrm{Y}_{\mathrm{K}}=$ Keteguhan rekat menggunakan bahan pengisi kaolin

$\mathrm{X}_{\mathrm{T}}=$ Bahan pengisi tepung tempurung kelapa

$\mathrm{X}_{\mathrm{K}}=$ Bahan pengisi kaolin

Gambar 2 Hubungan antara kadar pengisi (filler) dengan keteguhan rekat.

\section{Kesimpulan}

Kualitas perekat LF memenuhi standar Indonesia. Karakterisasi perekat $\mathrm{TF}$ adalah cairan perekat berwarna cokelat kemerah-merahan dan tidak terdapat bahan asing, kadar resin padat berkisar antara 31,85-35,68\%, viskositas 1,2 poise, keasaman $(\mathrm{pH})$ 11,5 dan waktu tergelatinasi berkisar antara 24,20-25,96 menit. Jenis dan kadar bahan pengisi berpengaruh nyata terhadap keteguhan rekat kayu lapis sengon. Peningkatan kadar bahan pengisi cenderung menaikkan keteguhan rekat kayu lapis sampai kadar 30\%. Kayu lapis yang dihasilkan baik menggunakan bahan pengisi tepung tempurung kelapa maupun kaolin sampai dengan kadar $30 \%$, keteguhan rekatnya memenuhi persyaratan Standar Jerman. Nilai keteguhan rekat maksimum diperoleh pada perekat yang menggunakan kedua jenis bahan pengisi sebanyak $10 \%$.

\section{Daftar Pustaka}

Achmadi SS. 1990. Bahan Pengajaran Kimia Kayu. Bogor: Institut Pertanian Bogor.

Balfas J. 2010. Jenis kayu alternatif untuk pertukangan. Prosiding Seminar Nasional Inovasi Teknologi Pengolahan Jati Cepat Tumbuh dan Kayu Pertukangan Lainnya; 2010 November 25; Bogor, Indonesia. Bogor: Puslitbang Keteknikan Kehutanan dan Pengolahan Hasil Hutan. hlm 98-107.

[DIN] Deutsches Institut für Normung. 1975. DIN Taschenbuch 60. Berlin: Beuth Verlag Cmbh.

Filoteo AG. 1972. Filler and extender foriredecom technical note. Manila: Philippines.

Hendradi TC. 2012. Statistik Six Sigma dengan Minitab. Panduan Cerdas

J. Ilmu Teknol. Kayu Tropis Vol. 17 No. 2 Juli 2019 
Inisiatif Kualitas. Yogyakarta: Andi Offset.

[KLHK] Kementerian Lingkungan Hidup dan Kehutanan. 2016. Statistik Kementerian Lingkungan Hidup dan Kehutanan Tahun 2015. Jakarta: Kementerian Lingkungan Hidup dan Kehutanan.

Kliwon S, Iskandar MI. 2008. Teknologi Kayu Lapis dan Produk Sekundernya. Bogor: Badan Penelitian dan Pengembangan Kehutanan.

Kollmann FFP, Kuezi EW, Stamm, AJ. 1975. Principle of Wood Science and Technology: II Wood Based Material. New York: Springer, Verleg Berlin Heidenberg.

Landrock AH, Ebnesajjad S. 2008. Adhesives Technology Handbook. New York: William Andrew.

Maloney TM. 1977. Modern Particleboard and Dry-Process Fiberboard Manufacturing. San Fransisco: Millerfreeman publication.

Pizzi A. 1998. Wood/bark extracts as adhesives and preservatives. Di dalam: Bruce A, Palfreyman JW (editors) Forest Products Biotechnology. London: Taylor $\&$ Francis Pub.

Prayitno TA. 1986. Ekstender dan filler pada perekatan kayu lapis. Duta Rimba. XII: 77-78.

Rachmawati O, Sugita P, Santoso A. 2018. Sintesis perekat tanin resorsinol formaldehida dari ekstrak kulit pohon mangium untuk peningkatan kualitas batang sawit. JPHH. 36(1):33-46. https://doi.org/10.20886/jphh.2018.36.1.3 3-46

Ruhendi S, Koroh DN, Syamani FA, Yanti H, Nurhaida, Saad S, Sucipto T. 2007. Analisis Perekatan Kayu. Bogor: Fakultas Kehutanan, Institut Pertanian Bogor.

Santoso A. 2001. Uji coba pembuatan perekat tanin. Laporan Hasil Penelitian. Bogor: Indonesia.

Santoso A, Sulastiningsih IM, Pari G, Jasni J. 2016. Pemanfaatan ekstrak kayu merbau untuk perekat produk laminasi bambu. JPHH. 34(2):89-100. https://doi.org/10.20886/jphh.2016.34.2.8 9-100

Setyarini A. 2007. Pengaruh penambahan hardener dan ekstender dalam perekat TRF (Tanin Resorsinol Formaldehida) terhadap eimisi formaldehida kayu lapis. [Skripsi]. Bogor: Fakultas MIPA, Universitas Nusa Bangsa.

[SNI] Standar Nasional Indonesia. 1998. Kumpulan SNI Perekat. Jakarta: Badan Standardisasi Nasional.

Sudjana. 2004. Desain dan analisis eksperimen. Bandung: Tarsito.

Sutigno P. 1988. Pengaruh ekstender dan pengisi dalam perekat urea formaldehida terhadap daya rekat kayu lapis meranti (Shorea sp.) dan kapur (Dryobalanops sp.) [Disertasi]. Bogor: Institut Pertanian Bogor. 